\title{
TEACHING ASSESSMENT TO DEVELOP ESP STUDENTS' SPEAKING SKILLS
}

\author{
UDC 371.26:811.111'276.6
}

\author{
Branislava Ličen, Vesna Bogdanović \\ University of Novi Sad, Faculty of Technical Sciences, Novi Sad, Serbia
}

\begin{abstract}
The demand for changing the conceptions of teaching and learning has brought peer- and self-assessment into the classroom. This paper presents the challenges teachers have to face while preparing the assessment process for the ESP classroom, with a special emphasis on developing ESP students' speaking skills. It is of primary importance that teachers know how to prepare the assessment criteria, how to instruct students on this topic and provide them with adequate feedback while avoiding possible barriers and misunderstandings along the process. The paper further demonstrates how students become active participants in the learning process and are asked to contribute in providing assessment criteria and feedback. While learning speaking skills, students also learn how to assess themselves and others. That enables them to raise awareness of the most common problems and mistakes they encounter when developing their communication skills and increases the overall level of their language ability and performance. As a result, teachers might dedicate more time to other useful classroom activities.
\end{abstract}

Key words: peer-assessment, self-assessment, speaking skills, teacher training, assessment criteria

\section{INTRODUCTION}

Teaching assessment is essential in helping students gain the strategies necessary for developing their speaking and oral presentation skills. The importance of enabling students to deliver a good oral presentation as a part of a number of essential work-place tasks, such as presenting engineering solutions and project proposals, selling products and conducting professional seminars and meetings, is well documented in the literature and includes the need to develop effective oral communication skills. Furthermore, oral presentation skills are not only useful in the professional setting, but also in the academic setting and at the interpersonal level. The ability to offer a good presentation will

Submitted July $8^{\text {th }} 2017$, accepted for publication December $13^{\text {th }}, 2017$

Corresponding author: Vesna Bogdanović

Faculty of Technical Sciences, Dositeja Obradović Square 6, 21000 Novi Sad, Serbia

E-mail: vesna241@uns.ac.rs 
improve students' confidence, enhance their future study options and help them share what they have learned with others.

Some of the most common problems related to students' speaking skills are the lack of cohesive elements when giving a presentation, the lack of an adequate introduction and conclusion, failure to use visual aids successfully, etc. (Knežević, 2012). This paper will discuss the extent of the role of the teacher in the possibility to overcome these problems by teaching assessment to ESP students, using both peer- and self-assessment methods within a formative assessment strategy in the classroom, and examine if this knowledge can be positively transferred to the ESP students' speaking ability.

\section{ASSESSMENT ROLES AND TYPES}

Assessment should be regarded as an integral part of the teaching and learning process, meaning that teaching methods and assessment practices have to be in accordance with the learning objectives (Brown, et al., 1997; Heywood, 2000). Likewise, learners should be actively involved and play an active role in the process of learning and assessment. In order for the assessment tasks to be meaningful and authentic, students should also participate in their development, as well as document their learning through reflections.

In developing speaking skills, formative or continuous assessment can assist students in identifying their weaknesses and strengths. In contrast to summative assessment in which the teacher or institution judge the achievement in its totality, formative assessment allows the learner to judge their own learning achievement. Formative assessment is administered throughout the learning process as an effort to continually inform both teacher and student during the learning process.

There have been promising indications that, by providing the student with both internal (self-comparison) and external (assessor provided) feedback, formative assessment can enhance their language performance learning outcomes. Formative feedback given to the students also means that they are taught relevant oral presentation criteria by which they can judge their own performance and progress. Several benefits of formative assessment have been pointed out by Black and William (1998, p. 141), such as (a) empowering learners to recognize the areas in which they can improve themselves, (b) improving learner motivation, and (c) raising a level of awareness for both learner and teacher during the learning process. Additional studies have shown that formative assessments help teachers identify the needs of the student and foster learning in the classroom environment.

One type of formative assessment involves self-assessment by individual learners. It is not commonly used in schools and at universities, but with new technologies being available, computer-based self-assessment in which students can compare their performance to the responses of others, ideally native speakers, is today another viable option. It can be helpful in assisting the student to gain insights to their own progress or the lack of progress, and can increase learning outcomes (Butler \& Jiyoon, 2010). Apart from these benefits, one of the advantages of self-assessment in general is that, unlike other assessment-oriented communication activities such as group discussions, role play, oral presentations, etc., it does not consume class time, since the student can go through the process of self-assessment at home. Self-assessment develops students' responsibility for learning and their judgement skills. Correctly implemented, self-assessment can promote intrinsic motivation, internally controlled effort, mastery goal orientation and more meaningful learning (McMillan \& 
Hearn, 2008). In self-assessment, students identify actions and elements needed for their personal improvement, and they plan their next step, i.e. they define their short- and longterm individual goals.

It is important to emphasize once again that in order to be able to carry out selfassessment, students need to be aware of the evaluation criteria designated by the teacher. However, one key issue that is yet to be resolved is that of weak reliability due to subjective observations involved with formative self-assessments. If students are not trained well on how to evaluate their own work, then outcomes may vary greatly amongst students. Students may also feel ill equipped to undertake assessment, and their reluctance may lead to unreliable results, as well as dissembling and dishonesty. Teachers can help by setting the initial individual goals for students, providing follow-up support and feedback, scaffolding the learning (Vygotsky, 1978) and resetting the goals in the process.

Another type of formative assessment is peer-assessment, where students individually assess each other's knowledge. It encloses the same criteria and judgement processes as selfassessment, with the difference that one has to know how to be objective in relation to other student's work. In peer assessment, students are encouraged to actively participate in the grading process and provide relevant feedback to their peer students. They take the responsibility to present positive criticism, demonstrating their knowledge and at the same time responding to other student's knowledge and advancement. This assessment can be influenced by friendship and reluctance to utter negative criticism. At the other extreme, some students may be discriminated if students decide to act against a group member.

Self- and peer-assessment can aid the teacher in the classroom by reducing their marking load and helping them provide a more objective grade, assuming that students are trained properly. When asked about concerns related to peer- and self-assessment (Ross, 2006), teachers reported the fear of lowering the standards of grading, inability of students to comprehend and use assessment correctly, inability of parents to appreciate the process, preparation of criteria and feedback that may not be included in the course grade, and building the classroom environment of trust and positivity with the emphasis on improving what students ultimately learn. To answer these concerns, the teacher has to spend time training students on assessment and providing adequate assessment criteria.

\section{TEACHERS' WORKLOAD AND CONSIDERATIONS}

The role of the teacher in the process of self- and peer-assessment includes many considerations and the changing role in teachers' perspectives, which has been argued about in a number of studies (Rolheiser \& Ross, 2001; Andrade, 2010; Hyland, 2013). Teachers have to learn more about the pedagogy and implement it in classes. They need to do a lot of research and then put it in practice, needing a variety of examples of implementation. They have to give up control in their classrooms disregarding their own fear (Rolheiser \& Ross, 2001) and need to start getting involved in a different relationship with students. The changes also imply moderating the classroom dialogue and using feedback to a greater extent.

There are a number of very important considerations for the teacher to be aware of if one decides to ask students to peer- and self-assess. Teachers need to implement strategies that encourage and foster honest self-reflection. Brown and Harris (2014, p. 26) argue that teachers need to permit some self-assessment to remain private from the teacher, without 
forcing students to display their negative assessment in front of the class. They should also encourage students to share their self-evaluations with trusted people, like best friends or a family member. This is in accordance with Andrade (2010, p. 12) who believes that teachers should focus on the self-regulatory effects of self- and peer-assessment, supporting students in articulating subsequent learning in their own words and information they want to share. Since teachers know that reacting negatively to student self-assessment would be counterproductive, it is desirable for them to comment on the realism and objectivity of the assessment as an important learning objective. It will provide an environment where students' opinions are prioritized and protected, and a classroom with a supportive interpersonal climate. Therefore, it is clear that teachers, as well as students, should undergo training before being engaged with peer- and self-assessment as a taught and learned competence (Brown \& Harris, 2014, p. 27), as well as be prepared for certain changes and corrections being undergone within the process itself (Min, 2013).

There are a number of steps that the teacher has to take to ensure that their students learn how to peer- and self-assess effectively (Rolheiser \& Ross, 2001). Students have to understand both what peer- and self-assessment is and how it is used to support learning. In general, the process of self-assessment includes three steps (Andrade, 2010, p. 4): articulating expectations, critique of work in terms of expectations, and revising. While the latter two can and should be done by students themselves, where the teacher is only there to monitor and direct if necessary, the first step includes a detailed preparation on behalf of the teacher.

Rolheiser and Ross (2001) suggest the following key stages for teacher reflection: (a) establishing the assessment criteria - the teacher generates the relevant criteria and negotiates them with students; (b) teaching students how to apply the criteria - providing examples and models; (c) giving feedback to students on their assessment - the teacher provides comprehensive feedback linked to criteria and the student is engaged in a dialogue about peer- and self-assessment; (d) goal setting - teacher prescribes goals appropriate for students and tasks; and (e) classroom norms - students peer- and self-assess regularly throughout the course of instructions, using a variety of instruments. These will be discussed further in the paper.

\section{ASSESSMENT CRITERIA}

In order to be able to deliver a good oral presentation, students need to become aware of the assessment criteria, or significant oral presentation factors, that, if fulfilled, will lead to a wanted outcome. One of the problems teachers and educators are faced with is which significant factors to choose out of a relatively wide range offered by different authors and researchers. Since most teachers use criterion-referenced assessment rather than just give a single grade for a presentation as a whole, their first task is to find available criteria, test them in classes, and establish the best possible one for their students. The difficulty of criteria selection is further expanded by knowing that each generation of students is different and that they all have to find the criteria suitable for self- and peerassessment. Only then should the teacher focus their training on different competencies that comprise the assessment tasks at hand.

Newbrook and Wilson (2002, p. 20), recommend that the following criteria should be considered when marking a candidate's speech: grammatical resource, i.e. the range and 
accuracy of structures (tenses, prepositions, etc.); lexical resource, or the range and appropriateness of vocabulary used; discourse management, or the relevance and coherence of language used and the ability to link ideas together; pronunciation, i.e. the acceptable rhythm, intonation and pronunciation of individual sounds; and, interactive communication: the linguistic resources and strategies used in exchanging information and social interaction.

In addition to the separately graded competences, there is also a global achievement grade for the candidates' overall performance. However, neither one of the sets of criteria listed above pays due attention to nonverbal presentation factors, i.e. involving the audience and using visual aids and prompts. On the other hand, teachers try to strike a balance between the content and delivery focused factors, as well as between the linguistic expression and nonverbal aspects of any presentation. Therefore, a list of eight most significant presentation factors was devised to facilitate both the training and assessment processes. These are: content, structure, grammar, coherence, vocabulary, speaking skills, involving the audience and self-presentation. The use of visual aids was not listed as a separated category, since their use should not be made mandatory when considering the quality of a presentation. However, it could be placed within the 'involving the audience' category under which it was presented to the students.

As it can be observed from the list, students can decide on the content, structure and vocabulary they are going to use. They can apply the grammar they have already mastered. Nevertheless, they have to be taught about coherence, speaking skills, communication with the audience and self-presentation in a number of classes organized by the teacher.

\section{THE INSTRUCTION AND APPLICATION OF CRITERIA}

Instruction or training on the relevant speaking skills' criteria has been proved to be the most important phase of the process, since it fulfils the most relevant goal of the teacher, that is, it actually teaches the students how to speak effectively in front of an audience. In classroom, one of the possibilities is to have classes focused on each speaking skill and oral presentation factor separately, asking students to rehearse parts of their own short presentations at home and delivering them in the following class, paying special attention to that one presentation factor discussed in the previous class. Volunteers can then give their short speeches as examples of the previous week tutorial and the quality of their work can be discussed and extensive feedback offered, so that both the speakers and the audience become aware of how they could improve their speeches in the future and how they can peer- and selfassess them along the way.

For example, concerning the speech content, the instructions may note that a person giving an oral presentation should talk about a single topic without digressing to other subjects/topics. The topic should be discussed in more detail and interesting examples should be offered. To be able to present the content successfully, students are advised to use notes rather than a full script, since their use allows the speaker to be prepared, yet still appear spontaneous. Likewise, students should learn the basic introduction-body-conclusion organizational pattern. They have to be familiarized with thesis/topic sentences, introduction and supporting sentences, as well as coherence. As it has already been pointed out, one of the main problems speakers encounter is a lack of coherence, or the inability to make a presentation sound right as a whole. Therefore, a well ordered and logical flow of ideas presented should also be brought to students' attention, as well as the need for the repetition, re-wording and summarization in individual organization units. 
Grammatical considerations seem to be obvious to students, since they are required to use grammatically correct sentences early on during the course of their education. The vocabulary criterion, on the other hand, needs instruction in selecting the most appropriate words in order to convey precise meanings, as well as in using a wider range of words and expressions to make the speech more vivid and effective. Students should also be trained in the use of register, metadiscourse and linking expressions, as well as the situation appropriate phrases for introducing a subject, involving the audience, presenting argumentation, ordering points, starting a new section, referring to visual aids, defining, rephrasing, giving examples and offering conclusions.

Speaking skills refer to the voice/speech traits such as volume, intonation, fluency, expression, clarity and projection, but they also include pace and pause. Teachers should provide examples, measurable in terms of loud/soft, clear/unclear, fast/slow and acceptable/ unacceptable. Attention should be drawn to making pauses rather than rushing through their notes, emphasizing certain points of the presentation and involving the audience. Teacher can encourage students to raise interest by offering examples, anecdotes, impressive statistics and interesting quotations. Time in classes should also be spent about advantages of digital presentations and handouts. Speakers can also be encouraged to ask rhetorical questions that might and might not get an answer, to ignite deeper interest in the topic, and leave time for the listeners' questions.

Self presentation is also a significant speech factor which refers to several different presentation skills and aspects. First of all, there is the body language, gestures and eye contact. According to Myhill (2006, p. 13), if an instructor says one thing and their body language communicates another thing, the students are more likely to believe the nonverbal messages. The training should also include helping students to be self confident, express one's personality, i.e., establish some sort of a pleasant relationship with the audience, be open and show a sense of humour.

The teacher should teach critical thinking skills required for peer- and self-assessment practice. They should engage students in discussions or activities focused on assessment, they should be allowed the time for learning assessment skills, and they should be provided with a number of opportunities to practice different aspects of the assessment process. Since students need to know the aim of the process, the teacher has to develop, in agreement with students, clearly articulated learning targets and concrete exemplars of student work. The teacher should also define language that is meaningful for the learners, i.e. determine language used for reflection and self-assessment. Exemplars have proven themselves to be effective since they provide explicit knowledge on what is required, defining a valid standard against which students can compare their performances. On the other hand, written statements describing assessment criteria are not so good due to not being multidimensional and if written, have to be elaborated orally in classes. It has been shown (Rolheiser \& Ross, 2001) that the accuracy of self-assessment is improved when students are taught how to peer- and self-assess in a systematic way, and that creativity and class adaptation influence the success of assessment.

\section{FEEDBACK}

In the assessment process, one of the teachers' tasks is to select the appropriate feedback method to be used in the self- and peer-assessment process, adapting it to suit the various needs of diverse student populations. The teacher then needs to present these 
methods to students and provide them with the opportunity to commonly determine the best possible exploitation and outcomes from them. Same as teaching their students, teachers also need time to learn the tools and strategies as they promote a shift away from quantitative to qualitative learning.

Nicol and Macfarlane-Dick (2006, p. 204) summarize good feedback practice with seven principles: (a) feedback helps clarify what good performance is; (b) it facilitates the development of peer- and self-assessment in learning; (c) it delivers high quality information to students about their learning; (d) it encourages the teacher and peer dialogue around learning; (e) it encourages positive motivational beliefs and self-esteem; (f) it provides opportunities to close the gap between the current and desired performance; and ( $\mathrm{g}$ ) it provides information to teachers that can be used to help shape the teaching. Bearing this in mind, some of the possible feedback strategies for self- and peer-assessment may include checklists, rubrics, audio and video recordings, portfolios, interviews, and journal logs.

Checklists are observed as an easy-made method, quick and useful in involving a large number of criteria (Cleland, 1999). Monitoring one's progress using checklists can help learners develop metacognitive skills, enhance their learning strategies, and assist them in becoming independent, confident learners. They can be developed by students themselves, and they can monitor their strengths and weaknesses, knowing what they have to improve in the future work. Possible disadvantages include students who choose not to be engaged in too detailed recordkeeping, making it impossible for the teacher to provide accurate feedback. Hence, the teacher has to participate in frequent interaction with students to obtain better results.

Ready-made rubrics can also be used as a starting point. However, if they are modified in collaboration with students (Andrade, 2010; Davies, 2000), they can include student-friendly language and understandable criteria, providing a model for students. Since students are actively involved in the creation of rubrics, they will be more motivated and will take greater pride in their work. "Creating a rubric teaches as to think." (Spandel, 2006, p. 16). Rubrics can be observed as a road map for helping students in the learning process and providing a constructive feedback.

Videotaping students during their oral presentations can be useful for self- and peerassessment as well. Students can discuss their performances in small groups, and they can use checklists for self-assessment while viewing or listening to the tape.

Throughout the process, students have to understand that peer- and self-assessments are formative and used to improve their overall performance (Ross, 2006, p. 6). However, the motivation and self-esteem of students will affect students' responses to feedback and their commitment to self-regulation of learning. One of the tasks of the teachers is to enhance students' motivation in order to benefit most from the feedback (Yang, 2016). If teachers make an effort to understand the potential positive consequences of formative assessment, it can then become a supportive act through intervention, and students can regard the outcomes rather than the momentary criticism.

\section{CONCLUSION}

Assessment plays an important role in the classroom. With a number of benefits and a number of challenges, it has been embraced in classes where students are intellectually challenged, where groups are large and teachers need a shift in grading and perspective on students' outcomes. The paper has tried to present the benefits of peer- and self-assessment in 
ESP classes, stressing the important issues to be considered throughout the process of introducing, training and delivering assessments.

Special attention has been attributed to the teachers' workload. Even though the grading burden has been diversified and removed from the classroom, the teacher is left with a lot of tasks to be considered and fulfilled. Beginning with the idea of self- and peerassessment, teachers need training in the change of their perspectives on grading and their perspective on students and their obligations. They need knowledge of psychology to be able to cope with parents and all the possible situations with students' private observations. They need to know how to encourage students to share their beliefs and opinions, and present their progress in learning. After that being learnt, teachers need to prepare criteria for assessment, teach students, evaluate their deliveries and provide adequate and positive feedbacks. In the end, assessment proves to be a time-consuming process, though rewarding both for the teacher and, what is really important, for the student as well.

\section{REFERENCES}

Andrade, H. L., (2010), "Students as the definitive source of formative assessment: Academic self-assessment and the self-regulation of learning", NERA Conference Proceedings $2010 . \quad$ Paper 25.http://digitalcommons.uconn.edu/nera_2010/25 Accessed 04.04.2016.

Black, P., \& William, D., (1998), "Inside the black box: Raising standards through classroom assessment", Phi Delta Kappa, 80, 139-144.

Brown, G., Bull, J. \& Pendlebury, M., (1997), Assessing student learning in higher education, Routledge, London.

Brown, G. T. L., \& Harris, L. R., (2014), “The future of self-assessment in classroom practice: Reframing selfassessment as a core competency", Frontline Learning Research 3:pp. 22-30.

Butler, Y. \& Jiyoon, L., (2010), "The effects of self-assessment among young learners of English", Language Testing, 27, 5-15. DOI: https://doi.org/10.1177/0265532209346370

Cleland, J., (1999), "We can charts: Building blocks for student led conferences", The Reading Teacher, 52(6), 588-595. URL: http://www.jstor.org/stable/20202131

Davies, A., (2000), Making classroom assessment work, Connections, Courtenay, British Columbia, Canada.

Heywood, J., (2000), Assessment in higher education: Student learning, teaching, programmes and institutions, Jessica Kingsley, London.

Hyland, K., (2013), "Student perceptions of hidden messages in teacher written feedback", Studies in Educational Evaluation, 39, 180-187. URL: http://hdl.handle.net/10722/199627

Knežević, Lj., (2012), "Kognitivne i metakognitivne strategije u funkciji bolje organizacije usmenih izlaganja studenata”. In: B. Radić-Bojanić (Ed.), Strategije i stilovi u nastavi engleskog jezika (pp. 59-71). Novi Sad: Filozofski fakultet. UDK 371.3:811.111.378.4

McMillan, J. H., \& Hearn, J., (2008), "Student self-assessment: The key to stronger student motivation and higher achievement", Educational Horizons, 87(1), 40-49. URL: http://www.eric.ed.gov/ERICDocs/data/ericdocs2sq1/content_storage_01/0000019b/80/41/9e/80.pdf

Min, H., (2013), "A case study of an EFL writing teacher's beliefs and practice about written feedback", System, 41, 625-638. DOI: https://doi.org/10.1016/j.system.2013.07.018

Myhill, D., (2006), Talking, listening, learning: Effective talk in the primary classroom, Open-University Press, New York.

Newbrook, J., \& Wilson, J., (2002), New proficiency gold coursebook, Pearson Education Limited, Edinburgh Gate, Essex.

Nicol, D. J., \& Macfarlane-Dick, D., (2006), "Formative assessment and self-regulated learning: A model and seven principles of good feedback practice", Studies in Higher Education, 31(2), 199-218. DOI: http://dx.doi.org/10.1080/03075070600572090

Rolheiser, C., \& Ross, J. A., (2001), "Student self-evaluation: What research says and what practice shows", In R. D. Small \& A. Thomas (Eds.), Plain talk about kids (pp. 43-57). Covington, LA: Center for Development and Learning. http://www.cdl.org/resource-library/articles/self_eval.php. Accessed: 26.10. 2013. 
Ross, J. A., (2006), “The reliability, validity, and utility of self-assessment”, Practical Assessment Research and Evaluation, 11(10), 1-13.

Spandel, V., (2006), "Speaking my mind: In defense of rubrics", The English Journal, 96(1), 19-22. DOI: $10.2307 / 30046656$

Vygotsky, L., (1978), Mind in society: The development of higher psychological processes. Harvard University Press, Cambridge, MA.

Yang, J. (2016), "Learners' oral corrective feedback preferences in relation to their cultural background, proficiency level and types of error", System, 61, 75-86. DOI: 10.1016/j.system.2016.08.004

\section{PODUČAVANJE SPOSOBNOSTI EVALUACIJE U CILJU POBOLJŠANJA VEŠTINE GOVORA U NASTAVI JEZIKA STRUKE}

U poslednjih nekoliko decenija prisutni su novi trendovi i koncepti u vezi sa podučavanjem i učenjem jezika struke, što je međusobnu i samo-evaluaciju studenata približilo nastavnom procesu. Ovaj rad govori o izazovima sa kojima se nastavnici suočavaju pripremajući proces evaluacije u nastavi jezika struke, pri čemu se akcenat stavlja na razvijanje govornih veština studenata. Od izuzetnog je značaja da nastavnik ispravno definiše i pripremi kriterijume evaluacije, da ih vešto prenese studentima i pruži im odgovarajuće povratne informacije, prevazilazeći poteškoće i nesporazume sa kojima se susreće tokom procesa. Rad dalje analizira način na koji studenti postaju aktivni učesnici u procesu učenja, te se od njih zahteva da doprinesu diskusiji o kriterijumima evaluacije, ali $i$ da pruže adekvatne povratne informacije. Razvijajući govorne veštine, studenti istovremeno uče kako da evaluiraju svoj govor, kao $i$ govor svojih kolega. Na taj način, podiže se njihova svest o najučestalijim problemima i greškama sa kojima će se susresti tokom rada na razvijanju veština komunikacije i povećava se njihova ukupna jezička sposobnost. Još jedna pozitivna posledica međusobne $i$ samo-evaluacije studenata je i činjenica da će nastavnik moći više vremena da posveti drugim korisnim nastavnim aktivnostima.

Ključne reči: međusobna evaluacija studenata, samo-evaluacija, govorne veštine, obuka nastavnika, kriterijumi evaluacije 